\title{
DAMPAK KEBIJAKAN GERAKAN LITERASI SEKOLAH SEBAGAI UPAYA MENUMBUHKAN MINAT BACA SISWA SMA DI KOTA BALIKPAPAN
}

\section{THE IMPACT OF SCHOOL LITERATION MOVEMENT AS AN EFFORT TO GROW READING INTEREST IN HIGH SCHOOL STUDENTS IN BALIKPAPAN CITY}

\author{
Bambang Suwardi Joko \\ Pusat Penelitian Kebijakan Pendidikan dan Kebudayaan, Balitbang Kemdikbud \\ bambang_tito@yahoo.com
}

Naskah diterima: 26 Agustus 2019; direvisi akhir: 20 Desember 2019; disetujui: 20 Desember 2019

\begin{abstract}
ABSTRAK
Tujuan penulisan ini adalah mengkaji dampak kebijakan gerakan literasi yang pernah diterapkan pemerintah Kota Balikpapan dan dampak bagi guru dan siswa dalam upaya menumbuh-kembangkan gerakan membaca, serta mendeskripsikan upaya apa yang dilakukan sekolah dan guru meningkatkan literasi siswa di sekolah. Kajian ini menggunakan metode deskriptif kualitatif dengan melakukan analisis deskriptif yang mencakup komponen pelaksanaan program pengajaran dalam mendorong siswa meningkatkan gemar membaca. Teknik pengumpulan data dilakukan dengan pengisian instrumen atau daftar isian, wawancara, observasi, dan diskusi kelompok terpumpun dengan responden 12 orang guru khusus mapel IPA yang di UN kan di tiga SMA negeri di Kota Balikpapan. Hasil penelitian menunjukkan bahwa tidak semua sosialisasi yang menjadi program pemerintah Kota Balikpapan sampai ke para guru, pihak sekolah sebatas mensosialisasikan kepada guru-guru mata pelajaran terkait seperti guru bahasa Indonesia. Dampak program gerakan literasi pemerintah kota bagi kalangan guru, sebanyak 41,67 persen guru menjawab ada dampaknya dan 58,33 persen tidak ada dampaknya. Salah satu program pemerintah kota, mematikan televisi setelah maghrib hingga pukul 11 malam merupakan program lama, yang perlahan mulai kurang diminati siswa. Upaya sekolah dalam menumbuhkan gerakan minat baca, seluruh guru menilai bahwa dampak kebijakan sekolah seperti membaca kitab suci di awal pelajaran anak menjadi rajin membaca buku keagamaan karena dibiasakan.
\end{abstract}

Kata kunci: dampak, literasi, siswa

\section{ABSTRACT}

The purpose of this paper is to examine the impact of literacy movement policy that has been applied by the Balikpapan City government and the impact on teachers and students in developing the reading interest, as well as describing what efforts are being made by schools and teachers to improve student literacy in schools. This study uses a qualitative descriptive method by conducting descriptive analysis that includes components of the implementation of teaching programs in encouraging students to enjoy reading. Data collection techniques were carried out by filling in instruments or questionnaires, interviews, observations, and group discussions with 12 respondents specializing in science subjects in the UN in three state high schools in Balikpapan. The results of the study showed that not all socialization 
programs that were made by the Balikpapan City Government reached the teachers, the school was limited to disseminating information to teachers of related subjects such as Indonesian language teachers. The impact of the municipal government literacy program for teachers, 41.67 percent of teachers answered that there was an impact and 58.33 percent said there had been no effect. One of the city government programs, turning off the television after sunset until 11 o'clock at night is an old program, which slowly begins to be less attractive to students. Regarding school efforts in fostering the reading interest, all teachers assess that the impact of school policies such as reading the scriptures at the beginning of the lesson has made children be more diligent in reading religious books because they are accustomed to it.

Keywords: impact, literacy, students.

\section{PENDAHULUAN}

Pembangunan

Pendidikan

dan

Kebudayaan diarahkan untuk mewujudkan nawa cita khususnya butir nomor 5, 6, dan 8 , yaitu meningkatkan kualitas hidup manusia Indonesia, meningkatkan produktivitas dan daya saing, serta melakukan revolusi karakter bangsa. Arah pembangunan pendidikan dan kebudayaan adalah terbentuknya insan serta ekosistem pendidikan dan kebudayaan yang berkarakter serta semangat gotong royong. Dalam upaya mendukung arah kebijakan tersebut dikembangkan program Literasi Nasional (Kemdikbud, 2017). Dalam Panduan Gerakan Literasi Sekolah (GLS) disebutkan bahwa GLS adalah sebuah gerakan dalam upaya menumbuhkan budi pekerti siswa yang bertujuan agar siswa memiliki budaya membaca dan menulis sehingga tercipta pembelajaran sepanjang hayat.

Dorongan dan motivasi dapat dilakukan oleh lingkungan keluarga. Karena jika lingkungan keluarga memperkenalkan bahan bacaan, maka anak akan dapat tergerak untuk melakukan kegiatan membaca. Dalam penjelasan (Muktiono, 2003: 16) 4 menyatakan bahwa "membaca buku dapat dikembangkan agar menjadi kegiatan yang melibatkan banyak orang, motivasi dan dorongan dari dalam individulah yang membuat kegiatan ini dapat dilakukan. Budaya membaca dapat dilakukan dengan peran-peran pribadi setiap individu untuk menekuni bacaan. Motivasi dan dorongan dalam membacakan dapat ditimbulkan oleh adanya kebiasaan dan contoh dari keluarga. Dapat dilihat dari hasil survei nasional yang dilakukan di Inggris dengan hasil yang menyatakan bahwa 82 persen responden setuju jika anak dapat menumbuhkan minat membaca anak karena didorong oleh peran orang tua (Gleed, 2013: 32).

Selain adanya dorongan dari peran keluarga dalam menumbuhkan minat baca. Motivasi lainnya berasal dari pengalamanpengalaman yang hadir dari sekolah. Menurut penelitian dari Jackson menjelaskan bahwa peran yang lebih besar terhadap kemajuan anak-anak di sekolah ialah peranan dari struktur dan organisasi sekolah atau peranan dari guru. Dari hasil penelitiannya mendapatkan hasil bahwa guru memegang peranan penting, dimana perhatian dari guru dapat memajukan perkembangan anak (dalam Gerungan, 2010: 208). Dapat terlihat jika perhatian dari guru untuk dapat memberikan motivasi dan dorongan pada anak untuk menjadikan sebagai seorang yang memiliki 
minat baca dapat dilakukan oleh peran guru. Seorang guru dapat menumbuhkan kegiatan membaca kepada anak karena mereka sering melibatkan dirinya dengan anak-anak di dalam kelas untuk memberikan pembelajaran dan metode menumbuhkan minat baca.

Dalam peraturan Undang-Undang Republik Indonesia Nomor 43 Tahun 2007 tentang Perpustakaan menegaskan bahwa budaya kegemaran membaca dilakukan melalui keluarga, satuan pendidikan, dan masyarakat dengan kerjasama antara pemerintah dalam upaya peningkatan minat baca, dimana pemerintah bertindak sebagai penanggungjawab utama dan pustakawan melakukan kinerja yang optimal.

Membaca merupakan bagian terpenting dalam peningkatan kualitas pendidikan yang lebih jauh lagi akan berpengaruh terhadap peningkatan sumber daya manusia. Dengan membaca akan banyak informasi yang didapat dan sekaligus menambah wawasan dan pengetahuan. Dengan demikian, membaca dijadikan sebagai suatu kebiasaan begitu penting, artinya setiap warga masyarakat harus membiasakan diri untuk membaca (Kamsul, 2011).

Meski kenyataannya minat dan budaya membaca menjadi salah satu masalah yang dihadapi oleh sekolah. Ketertarikan membaca oleh kalangan siswa menjadi faktor utama dalam membudidayakan kebiasaan membaca. Banyak faktor yang mempengaruhi minat baca di kalangan siswa rendah. Misalnya hasil penelitian minat baca siswa di SMAN 1 Lhokseumawe Aceh tahun 2010, menyimpulkan bahwa faktor yang menyebabkan berkurangnya minat baca pelajar SMAN 1 Lhokseumawe adalah jenis buku diperpustakaan yang kurang beragam, ruangan perpustakaan yang sempit dan kurang nyaman, petugas perpustakaan yang kurang ramah serta banyaknya tontonan dan permainan yang dapat mengalihkan minat siswa untuk membaca (Zulfannur, 2010).

Berdasarkan data World's Most Literate Nations peringkat minat baca Indonesia berada di urutan 60 dari 61 negara. Peringkat tersebut merupakan hasil penelitian dari Central Connecticut State University tahun 2016. Penelitian Miller mensintesis dua jenis variabel, yaitu tes prestasi literasi (PIRLS Kemajuan di International Reading Literacy Study dan PISA - Program Penilaian Pelajar Internasional) dan karakteristik perilaku melek (penduduk, surat kabar, perpustakaan, tahun sekolah). Tim memeriksa data untuk 200 negara, namun karena kurangnya statistik yang relevan, hanya 61 dibuat memotong (Miller, 2016) .

Survei terbaru OECD PIAAC (Organisation for Economic Co-operation and Development Programme for International Assessment of Adult Competencies) tahun 2016, bahwa kemampuan literasi masyarakat Jakarta dewasa (usia 25-65 tahun) lulusan minimal sekolah menengah atas, lebih rendah dibandingkan masyarakat Eropa di tingkat sekolah dasar. Kemampuan literasi orang Jakarta ini paling rendah dari 34 negara yang disurvei (Kompas, 2016). Demikian disebutkan bahwa data UNESCO tahun 2012 menunjukkan bahwa indeks tingkat membaca orang Indonesia hanyalah 0,001. Artinya, dari 1.000 penduduk, hanya ada 1 orang yang mau membaca buku dengan serius. Dengan rasio ini, berarti di antara 250 juta penduduk Indonesia, hanya 250.000 yang punya minat baca.

Kementerian Pendidikan dan Kebudayaan 
(Kemdikbud) merilis pencapaian nilai Programme for International Student Assessment (PISA), pada 6 Desember 2016. Rilis yang dilakukan bersama dengan 72 negara peserta survei PISA. Hasilnya, survei tahun 2015 menunjukkan kenaikan pencapaian pendidikan di Indonesia yang signifikan sebesar 22,1 poin. Hasil tersebut menempatkan Indonesia pada posisi keempat dalam hal kenaikan pencapaian murid dibanding hasil survei sebelumnya pada tahun 2012, dari 72 negara yang mengikuti tes PISA (Kemdikbud, 2016).

Menteri Pendidikan dan Kebudayaan, Muhadjir Effendy mengungkapkan, peningkatan capaian ini patut diapresiasi dan membangkitkan optimisme nasional, masih banyak PR untuk terus meningkatkan mutu pendidikan karena capaian masih di bawah rerata negara-negara OECD. Menurutnya, bila laju peningkatan capaian dapat dipertahankan, maka pada tahun 2030 capaiannya akan sama dengan rerata OECD. PISA merupakan sistem ujian untuk mengevaluasi sistem pendidikan dari 72 negara di seluruh dunia. Setiap tiga tahun, siswa berusia 15 tahun dipilih secara acak, untuk mengikuti tes dari tiga kompetensi dasar, yaitu membaca, matematika, dan sains. PISA mengukur apa yang diketahui siswa dan apa yang dapat dia lakukan (aplikasi) dengan pengetahuannya. Tema survei digilir setiap 3 tahun, tahun 2015 fokus temanya adalah kompetensi sains. Kepala Badan Penelitian dan Pengembangan (Balitbang) Kemdikbud, Totok Suprayitno, menyampaikan bahwa peningkatan capaian Indonesia tahun 2015 cukup memberikan optimisme, meskipun masih rendah dibanding rerata OECD. Berdasar nilai rerata, terjadi peningkatan nilai PISA Indonesia di tiga kompetensi yang diujikan. Peningkatan terbesar terlihat pada kompetensi sains, dari 382 poin pada tahun 2012 menjadi 403 poin di tahun 2015. Dalam kompetensi matematika meningkat dari 375 poin di tahun 2012 menjadi 386 poin di tahun 2015. Kompetensi membaca belum menunjukkan peningkatan yang signifikan, dari 396 di tahun 2012 menjadi 397 poin di tahun 2015. Peningkatan tersebut mengangkat posisi Indonesia 6 peringkat ke atas bila dibandingkan posisi peringkat kedua dari bawah pada tahun 2012 (Kemdikbud, 2016).

Tabel 1. 10 Negara dengan Peringkat Literasi Tertinggi

\begin{tabular}{ll}
\hline No. & Negara \\
\hline 1 & Finlandia \\
\hline 2 & Norwegia \\
\hline 3 & Islandia \\
\hline 4 & Denmark \\
\hline 5 & Swedia \\
\hline 6 & Swiss \\
\hline 7 & Amerika Serikat \\
\hline 8 & Jerman \\
\hline 9 & Latvia \\
\hline 10 & Belanda \\
\hline
\end{tabular}

Sumber: Worlds Most Literate Nations, Central Connecticut State University, 2016

Hasil tersebut menunjukkan betapa rendahnya minat baca masyarakat Indonesia yang mencerminkan ketidakakraban masyarakat dengan buku. Rendahnya minat baca masyarakat Indonesia juga terlihat dari data yang dilaporkan Badan Pusat Statistik (BPS) tahun 2010 memberikan bukti bahwa masyarakat Indonesia belum menjadikan membaca sebagai sumber utama mendapatkan informasi. Orang lebih memilih 
menonton TV $(85,9 \%)$ atau mendengarkan radio $(40,3 \%)$ ketimbang membaca Koran sebanyak 23,5\% (Hindarto, 2014).

Rendahnya kemampuan membaca siswa Indonesia, baik di tataran internasional maupun nasional, terpetakan di antaranya adalah faktor internal siswa seperti kebiasaan, minat, motivasi, dan budaya baca yang masih rendah; sistem pembelajaran membaca di sekolah belum memadai; isu literasi belum dijadikan dasar pengembangan kurikulum dan buku teks pelajaran serta buku pendidikan; ketersediaan sarana dan prasarana berupa buku di perpustakaan yang belum memadai; dan sistem penilaian yang masih lemah. Selain itu, pembelajaran membaca di kelas belum mengutamakan pengembangan kompetensi membaca, kebiasaan membaca belum dikembangkan secara memadai (Setiadi, 2011).

Terkait dengan budaya membaca, tidak terlepas dengan peran penting sebuah perpustakaan dan bahan bacaan di lingkungan sekolah. Mantan Mendikbud, Anies Baswedan yang juga penggagas gerakan 'Indonesia Mengajar', menyatakan bahwa agar membaca bisa menjadi budaya perlu beberapa tahapan. Pertama, mengajarkan anak membaca, lalu membiasakan anak membaca hingga menjadi karakter, setelah itu barulah menjadi budaya. Menurutnya, budaya membaca itu hadir karena ada kebiasaan membaca. Kebiasaan membaca ada jika ada rencana membaca secara rutin dan rutinitas dalam baca itu penting (Gewati, 2016).

Sebuah perpustakaan harus memberikan pelayanan dan manajemen yang baik dalam memberikan kebutuhan referensi siswa di sekolah. Jika perpustakaan adalah sebuah produk maka ia harus menjamin kualitasnya dengan baik. Studi demikian yang dilakukan Central Connecticut State University, New Britain CT, digunakan sebagai lensa untuk melihat perilaku melek huruf dan sumber daya yang mendukung - lima kategori seperti ukuran dan jumlah perpustakaan dan pembaca surat kabar.

Perpustakaan sekolah didirikan dengan tujuan, selain sebagai sumber informasi dan sumber belajar, juga diharapkan dapat digunakan yang sebagai sarana untuk menumbuhkan dan mengembangkan minat baca, kegemaran membaca dan budaya baca bagi siswa. Kembali pada minat membaca siswa, seperti pengalaman, tentang ketersediaan perpustakaan, walaupun perpustakaan ada, buku banyak, fasilitas memadai, tetapi yang masuk ke perpustakaan tidak ada. Minat baca, buku, dan perpustakaan adalah tiga elemen pokok dalam suatu sistem pendidikan yang dapat menciptakan kualitas sumber daya manusia. Sebuah negara yang kaya sumber daya manusia akan lebih unggul daripada suatu negara yang kaya sumber daya alam. (Sutrisno, 2009).

Jika melihat ketersediaan sarana perpustakaan SMA di Provinsi Kalimantan Timur berbanding dengan jumlah sekolah yang ada, dapat dikatakan belum semua sekolah memenuhi. Dari 215 SMA (data Statistik Persekolahan SMA 2017/2018, PDSPK, 2018) di Provinsi Kalimantan Timur meliputi 135 SMA negeri dan 80 SMA swasta, ketersediaan perpustakaan terdapat 135 perpustakaan di SMA negeri dan 80 di SMA swasta, artinya masih ada sebanyak 16 SMA negeri dan 25 SMA swasta tidak memiliki sarana perpustakaan.

Seperti halnya telah diamanatkan dalam Undang-Undang Nomor 43, Tahun 2007 
tentang Perpustakaan Bab XIII pasal 48 yang berbunyi: berisi "Pembudayaan kegemaran membaca dilakukan melalui keluarga, satuan pendidikan, dan masyarakat." (Republik Indonesia, 2007).

Komitmen Pemerintah dalam hal ini Kemdikbud dalam gerakan membaca, telah diwujudkan dalam bentuk Permendikbud Nomor 23 tahun 2015 mengamanatkan sekolah berkewajiban menyelenggarakan kegiatan membaca selama 15 menit sebelum pembelajaran (Kementerian Pendidikan dan Kebudayaan, 2015).

Dari latar belakang masalah di atas maka dapat ditarik pertanyaan penelitian yang dijadikan penelitian, yaitu: 1) bagaimana dampak kebijakan gerakan literasi yang dicanangkan pemerintah Kota Balikpapan bagi guru dan siswa dalam upaya menumbuhkembangkan gerakan membaca, dan 2) upaya apa saja yang telah dilakukan sekolah dan guru dalam menumbuhkan gerakan membaca bagi siswa.

Tujuan dari kajian ini adalah 1) mengkaji dampak kebijakan gerakan literasi pemerintah Kota Balikpapan dan dampak bagi guru dan siswa dalam upaya menumbuh-kembangkan gerakan membaca; dan 2) mendeskripsikan upaya apa yang dilakukan sekolah dan guru meningkatkan literasi siswa di sekolah.

\section{KAJIAN LITERATUR}

\section{Pemahaman tentang Literasi}

Gerakan Literasi Sekolah merupakan suatu usaha atau kegiatan yang bersifat partisipatif dengan melibatkan warga sekolah (peserta didik, guru, kepala sekolah, tenaga kependidikan, pengawas sekolah, Komite Sekolah, orang tua/wali murid peserta didik), akademisi, penerbit, media massa, masyarakat (tokoh masyarakat yang dapat merepresentasikan keteladanan, dunia usaha, dan lain lain), dan pemangku kepentingan di bawah koordinasi Direktorat Jenderal Pendidikan Dasar dan Menengah, Kemdikbud.

Menurut UNESCO "The United Nations Educational, Scientific and Cultural Organization", Literasi ialah seperangkat keterampilan nyata, terutama ketrampilan dalam membaca dan menulis yang terlepas dari konteks yang mana ketrampilan itu diperoleh serta siapa yang memperolehnya.

Herbert Kohl dalam bukunya Reading How to yang dikutip oleh Ahuja dan Ahuja (2010) menyatakan bahwa orang yang tidak sering atau tidak senang membaca atau menulis akan kesulitan mengajak orang lain membaca dan menulis serta sulit mengajar orang untuk menghargai apa yang orang tersebut hargai. Dari pernyataan di atas, sangat terlihat bahwa peserta didik harus membiasakan membaca karena peserta didik yang nantinya akan memberikan pengajaran kepada orang lain. Membaca juga menjadikan peserta didik lebih bisa menghargai orang lain.

Selain dengan adanya kegiatan yang dilakukan sekolah sebagai keterlibatan juga terdapat dukungan dari sekolah dalam menumbuhkan minat membaca anak. Peran sekolah ialah dengan adanya jenis dukungan yang dilakukan sekolah, yaitu membuat jam khusus membaca yang presentase sebanyak 78,9 persen. Sekolah membuat jam khusus membaca untuk anak dimana sesuai dengan salah satu pernyataan dari Seefeld yang menyatakan peran membentuk perilaku gemar membaca dapar dilakukan dengan membuat jam khusus membaca (Seefeldt, 
2008: 343).

National Institute for Literacy mendefinisikan literasi sebagai "kemampuan individu untuk membaca, menulis, berbicara, menghitung dan memecahkan masalah pada tingkat keahlian yang diperlukan dalam pekerjaan, keluarga dan masyarakat." Definisi ini memaknai literasi dari perspektif yang lebih kontekstual. Dari definisi ini terkandung makna bahwa definisi literasi tergantung pada keterampilan yang dibutuhkan dalam lingkungan tertentu.

Ada dua cara penting untuk meningkatkan budaya literasi membaca. Tidak sekedar kepentingan penilaian PISA, tetapi yang paling penting adalah memastikan pelaksanaan pelajaran membaca benarbenar dibangun untuk membentuk daya baca (Ibrahim, 2017). Pertama, menemu-kenali sebab-sebab terdalam mengapa siswa kurang sabar dan kurang cermat saat berhadapan dengan teks yang panjang dan dalam uji PISA. Kedua, merumus ulang paradigma pembelajaran membaca, tidak hanya melalui mata pelajaran bahasa (Indonesia dan Inggris), model pembelajaran membaca bagi seluruh mata pelajaran.

\section{Budaya Membaca di beberapa Negara}

Berdasarkan riset John W. Miller, Central Connecticut State University, menyebutkan negara Finlandia, merupakan salah satu negara di Eropa Utara yang menempati urutan nomor 1 di dunia sebagai negara paling literat (terpelajar) dalam bidang literasi. Amerika Serikat (USA), sebagai negara maju, juga menjadi salah satu negara paling berpengaruh termasuk dalam bidang literasi. Di negara paman Sam ini, rata-rata warganya yang berusia 18 tahun biasa menghabiskan membaca 11-20 buku dalam setahun.

Di Jepang, hampir 99 persen rakyat Jepang yang berusia 15 tahun ke atas, melek huruf (aksara). Artinya literasi disana sangat baik. Ini juga mengindikasikan bahwa masyarakat Jepang sangat gemar membaca. Bagi masyarakat Jerman, budaya layar (screen culture) yang melanda di era digital justru tidak mengikis budaya membaca rakyatnya. Sebagai negara maju Jerman benar-benar kokoh secara kultur. Dalam hal ini Jerman sangat patut dijadikan contoh. Eksistensinya justru mempengaruhi, bukan terpengaruh, ini wajar memang, karena mesin cetak ditemukan di Jerman. Secara emosional mereka (mungkin) masih sangat terikat dengan dampak penemuan mesin cetak tersebut. Dalam urusan membaca buku, animo masyarakat Jerman cukup tinggi, setidaknya sekali dalam sepekan mayoritas (lebih dari separoh) masyarakat Jerman membaca buku. Sebanyak $53 \%$ orang Jerman membeli buku untuk keperluan pribadi, dan $38 \%$ membeli buku untuk dihadiahkan kepada orang lain. Walau membaca buku bukan hobi nomor satu bagi orang Jerman, tetapi membaca buku di Jerman lebih populer ketimbang pergi ke mall, ke bioskop atau ke tempat-tempat lain yang menghabiskan uang. 
Tabel 2. Praktek Baik Budaya Membaca di Beberapa Negara

\begin{tabular}{|c|c|c|c|c|}
\hline Finlandia & USA & Jepang & Jerman & Australia \\
\hline $\begin{array}{l}\text { Selalu } \\
\text { ada maternity } \\
\text { package (paket } \\
\text { perkembangan } \\
\text { anak) dari } \\
\text { pemerintah bagi } \\
\text { orang tua yang } \\
\text { baru memiliki } \\
\text { anak. } \\
\text { Perpustakaan } \\
\text { ada di mana- } \\
\text { mana. } \\
\text { Budaya } \\
\text { membaca } \\
\text { didorong turun- } \\
\text { temurun. }\end{array}$ & $\begin{array}{l}\text { Rata-rata warga } \\
\text { yang berusia } \\
18 \text { tahun biasa } \\
\text { menghabiskan } \\
\text { membaca 11- } \\
20 \text { buku dalam } \\
\text { setahun } \\
\text { Sejak kecil } \\
\text { anak sudah } \\
\text { diperkenalkan } \\
\text { dengan buku. } \\
\text { Layanan toko } \\
\text { buku yang } \\
\text { sangat nyaman } \\
\text { dan ramah. } \\
\text { Harga buku } \\
\text { yang relatif } \\
\text { murah/ } \\
\text { terjangkau. }\end{array}$ & $\begin{array}{l}\text { Hampir } 99 \% \\
\text { rakyat Jepang } \\
\text { yang berusia } 15 \\
\text { tahun ke atas, } \\
\text { melek huruf } \\
\text { (aksara). } \\
\text { Tetap membaca } \\
\text { walau berada } \\
\text { di transportasi } \\
\text { umum. } \\
\text { Budaya Tachiy- } \\
\text { omi- Membaca } \\
\text { gratisan di toko } \\
\text { buku sambil } \\
\text { berdiri. } \\
\text { Tradisi mem- } \\
\text { baca } 10 \text { menit } \\
\text { sebelum masuk } \\
\text { kelas bagi siswa } \\
\text { di sekolah - } \\
\text { Diberlakukan } \\
\text { sejak SD den- } \\
\text { gan reward dan } \\
\text { punishment. }\end{array}$ & $\begin{array}{l}\text { Budaya layar } \\
\text { (screen culture) } \\
\text { yang melanda di } \\
\text { era digital dewasa } \\
\text { ini tidak mengikis } \\
\text { budaya membaca } \\
\text { masyarakat } \\
\text { Jerman. } \\
\text { Dalam sepekan } \\
\text { mayoritas (lebih } \\
\text { dari separoh) } \\
\text { masyarakat } \\
\text { Jerman membaca } \\
\text { buku. } \\
\text { Sebanyak 53\% } \\
\text { orang Jerman } \\
\text { membeli buku } \\
\text { untuk keperluan } \\
\text { pribadi dan } 38 \\
\text { \% membeli buku } \\
\text { untuk dihadiahkan } \\
\text { kepada orang lain. } \\
\text { Membaca buku } \\
\text { lebih populer } \\
\text { ketimbang } \\
\text { pergi ke mall, } \\
\text { ke bioskop } \\
\text { atau ke tempat- } \\
\text { tempat lain yang } \\
\text { menghabiskan } \\
\text { uang. }\end{array}$ & $\begin{array}{l}\text { Setiap hari saat pulang seko- } \\
\text { lah, anak diwajibkan memba- } \\
\text { wa pulang } 1 \text { buah buku ba- } \\
\text { caan. Sebagai PR untuk seti- } \\
\text { ap anak. Dalam hal ini orang } \\
\text { tua bertugas membimbing } \\
\text { anak-anak mereka membaca } \\
\text { buku tersebut. } \\
\text { Program Library Day, yang } \\
\text { berlaku setiap hari Kamis. } \\
\text { Pada hari itu anak diperbole- } \\
\text { hkan meminjam } 1 \text { buku ba- } \\
\text { caan untuk waktu seminggu } \\
\text { ke depan. }\end{array}$ \\
\hline
\end{tabular}

Sumber: desfortinmenulis.wordpress.com/2017/03/07

Dari tabel diatas terlihat sekali, bagaimana besarnya minat baca siswa-siswa di negara lain yang merupakan praktik baik bagi masyarakat Indonesia yang dapat diikuti. Namun demikian, tugas pemerintah setempat dan masyarakat dapat mewujudkan situasi literasi agar masyarakat bertambah besar minat baca. Pembiasaan yang mudah, dimulai dari kalangan keluarga, di Finlandia, orang tua punya tradisi mendongeng (dari buku cerita) sebelum tidur bagi anak-anak mereka. Selain itu, di Amerika, harga buku yang relatif murah dan terjangkau, serta Perpustakaan yang mudah diakses, ada di setiap kota.

Untuk beberapa daerah di Indonesia, bukan hal mudah menemui toko-toko buku, bahkan untuk mencari buku bacaan bekas dengan harga terjangkau, tidak jarang diantaranya harus pergi ke kota besar mencari buku yang murah. 


\section{Meningkatkan Minat Baca}

Minat baca adalah bentuk-bentuk perilaku yang terarah guna melakukan kegiatan membaca sebagai tingkat kesenangan yang kuat dalam melakukan kegiatan membaca karena menyenangkan dan memberikan nilai (Ginting, 2005).

Minat juga diartikan sebagai sikap positif terhadap aspek-aspek lingkungan. Ada juga yang mengartikan minat sebagai kecenderungan yang tetap untuk memperhatikan dan menikmati suatu aktivitas disertai dengan rasa senang. Aspek minat terdiri dari aspek kognitif dan afektif. Aspek kognitif berupa konsep positif terhadap suatu objek tersebut, sedangkan aspek afektif nampak dalam rasa suka atau tidak senang dan kepuasan pribadi terhadap objek tersebut.

Terdapat dua faktor yang dapat mempengaruhi minat baca siswa (Sutrisno, 2009). Pertama, faktor yang dapat meningkatkan minat baca siswa, tidak bisa terlepas dari pembinaan kemampuan membaca siswa. Tanpa memiliki kemampuan membaca tidak mungkin merasa senang membaca. Dalam rangka mengemban misi perpustakaan sekolah, guru, pustakawan selaku pengelola perpustakaan sekolah harus berusaha semaksimal mungkin membina kemampuan membaca siswa, sehingga tumbuh rasa senang membaca. Untuk dapat membina kemampuan membaca siswa, guru, pustakawan harus benarbenar memahami seluk-beluk membaca, sehingga membaca menjadi suatu kegiatan yang menyenangkan sekaligus bermanfaat. Pembinaan kemampuan membaca dalam rangka pembinaan dan pengembangan minat baca siswa akan berbeda-beda sesuai dengan tingkatan sekolah, semakin tinggi tingkatan sekolah seseorang akan lebih mampu membaca. Kedua, faktor pendukung minat membaca agar pembinaan dan pengembangan minat membaca siswa dapat berjalan dengan lancar dan baik, antara lain tersedianya perpustakaan yang memadai, bahan bacaan atau buku yang menunjang, dan memahami faktor penghambat minat baca.

Minat baca adalah keinginan atau kecenderungan hati yang tingggi (gairah) untuk membaca (Siregar, 2004 ). Definisi itu sejalan dengan pendapat Darmono yang menyatakan bahwa minat baca merupakan kecenderungan jiwa yang mendorong sesseorang berbuat sesuatu terhadap membaca (Darmono, 2001: 182). Minat baca tumbuh dari pribadi masing-masing seseorang, sehingga untuk meningkatkan minat baca perlu kesadaran setiap individu. Negara-negara maju, adalah Negara yang minat baca masyarakatnya tinggi. Oleh karena itu minat baca menduduki posisi penting bagi kemajuan suatu bangsa. Dibanding dengan Negara-negara yang tergabung dalam ASEAN dan negara asing lainnya, Indonesia masih menduduki urutan terbawah dalam hal minat baca. Di tingkat internasional, Indonesia memiliki indeks membaca 0,001. Hal itu berarti dalam setiap seribu orang, hanya satu orang yang memiliki minat baca tinggi. Kondisi itu jauh berbeda jika dibanding dengan Amerika yang memiliki indeks membaca o,45, dan Singapura 0, 55. Berdasarkan survey Unesco minat baca masyarakat Indonesia menduduki urutan 38 dari 39 negara yang diteliti. Laporan bank Dunia no.16369-IND (Education in Indonesi from Crisis to recovery) menyebutkan bahwa tingkat membaca usia kelas VI Sekolah Dasar di Indonesia hanya mampu meraih skor 51,7 
di bawah Filipina $(52,6)$, Thailand $(65,1)$ dan Singapura (74,0). Data Badan Pusat Statistik tahun 2006 menunjukan bahwa penduduk Indonesia yang menjadikan baca sebagai sumber informasi baru sekitar 23,5\%. Sedangkan yang menonton televisi $85,9 \%$ dan mendengarkan radio $40,3 \%$.

\section{METODE PENELITIAN}

Penelitian ini menggunakan pendekatan kuantitatif dengan tipe deskriptif dan metode yang digunakan adalah dengan metode survei, wawancara dan diskusi kelompok terpumpun (DKT). Alasan pemilihan survei sebagai metode dalam penelitian adalah karena populasi yang terlalu luas yang akan dijadilkan sasaran penelitian (Faisal, 2008: 23). Kota Balikpapan dipilih sebagai lokasi penelitian karena Pemerintah Kota Balikpapan tengah berupaya mewujudkan Kota Balikpapan sebagai kota literasi seperti halnya Kota Surabaya. Penelitian yang dilakukan melibatkan sekolah dan guru dengan sampel sejumlah 12 responden guru dari 3 SMA negeri.

\section{HASIL DAN PEMBAHASAN}

Dalam rangka meningkatkan budaya literasi bagi masyarakat Kota Balikpapan, menurut Disdik pemerintah Kota Balikpapan, pemkot setempat pernah memiliki program antara lain mematikan televisi setelah maghrib hingga pukul 23 malam. Akan tetapi menurut beberapa orang guru yang disampaikan saat DKT, program mematikan televisi hingga jam 11 malam tersebut telah luntur. Program lain yang masih berlaku adalah sebelum jam belajar pertama selesai, siswa wajib membaca kitab suci selama 15 menit, mengadakan lomba yang berkaitan dengan literasi seperti pidato, pemilihan duta baca pelajar Kota Balikpapan, lomba perpustakaan sekolah dan lain-lain.

Untuk menarik minat masyarakat datang ke perpustakaan, pemerintah daerah Kota Balikpapan berinovasi dengan menerapkan sistem e-book. Sebuah sistem yang mengubah buku manual ke dalam bentuk buku elektronik berbasis web. Sistem ini dipilih karena memudahkan pembaca untuk mengakses kategori buku yang ingin dibaca, dan juga sebagian besar masyarakat Balikpapan sudah memiliki peralatan pendukung, sehingga sistem ini diharapkan bisa diterima sekaligus disukai oleh seluruh lapisan masyarakat (Kantor Arsip dan Perpustakaan Kota Balikpapan).

Keseriusan pemerintah kota Balikpapan menuju kota Literasi adalah membuat kebijakan bagi semua pegawai harus membaca selama 10 menit (Pratikno, 2016). Kebijakan ini bukan hanya untuk sekolah dan warga sekolah, tetapi seluruh Satuan Perangkat Kerja Daerah (SKPD) harus membaca, yang selanjutnya diminta membuat resume atau menceritakan apa yang dibaca, kebijakan ini langsung dari Walikota. Dilakukan pula launching perpustakaan Balikpapan, 'Bundaku Baca'. Hal ini untuk menarik minat ibu untuk meningkatkan minat baca anak-anak di perpustakaan daerah.

Hasil dari penelitian menunjukkan bahwa, ditinjau dari tujuan pertama, yaitu mengkaji kebijakan pemkot Balikpapan dan dampaknya bagi guru dan siswa dalam upaya menumbuh-kembangkan gerakan membaca, adalah bahwa tidak semua guru di Kota Balikpapan mengetahui program gerakan membaca literasi. Hal ini menunjukkan sebesar 59 persen ( 7 orang guru) mengetahui 
program pemerintah kota, sebesar 33 persen (4 orang guru) tidak mengetahui program pemerintah kota, dan sebesar 8 persen (1 orang guru) yang tidak menjawab.

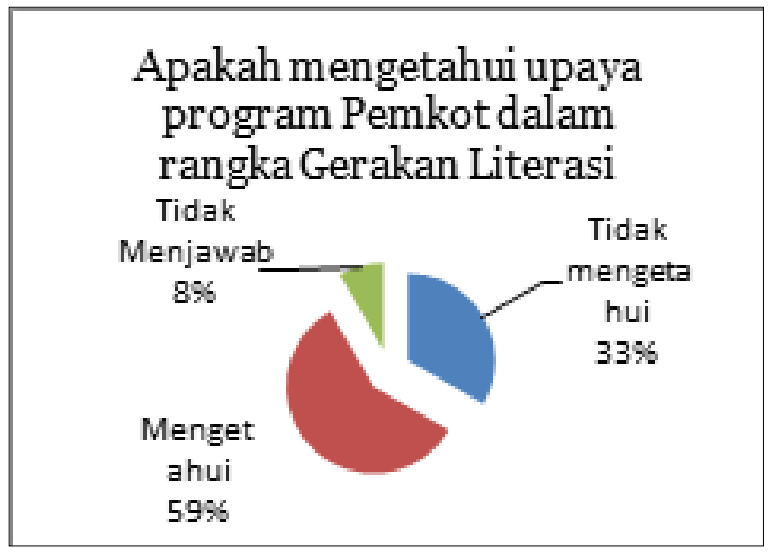

Gambar 1. Pengetahuan Guru terhadap Program Pemerintah Kota

Dari hasil wawancara diperoleh bahwa tidak semua sosialisasi tentang gerakan membaca yang menjadi program pemerintah Kota Balikpapan sampai ke para guru, seperti mengadakan lomba yang berkaitan dengan literasi pidato, duta baca dan lain-lain. Pihak sekolah sebatas disosialisasikan kepada guru-guru mata pelajaran terkait seperti guru bahasa Indonesia.

Hal ini pula diakui oleh guru mapel Bahasa Indonesia SMAN 5 kota Balikpapan, bahwa guru selalu meminta siswa untuk datang ke perpustakaan, dengan memberi info bahwa perpustakaan kota sudah menerapkan sistem e-book. Jadi memudahkan siswa untuk mengakses kategori buku yang ingin dibaca. Bahkan guru lebih memberi tugas untuk memancing siswa datang ke perpustakaan. Keterbatasan sarana perpustakaan juga diakui oleh guru senior ini, bahwa walaupun sudah ada sekolah yang memiliki perpustakaan secara mandiri, namun fasilitas yang terdapat pada perpustakaan sekolah, masih kurang dan cenderung apa adanya. Bahkan, banyak sekolah yang memiliki perpustakaan yang luasnya kurang memenuhi standar. Idealnya, standar luas sebuah perpustakaan di sekolah menurut Permendiknas Nomor 24 tahun 2007, minimal 144 meter persegi atau setara dengan dua ruang kelas untuk menampung 36 anak (Kemdiknas, 2007).

Menariknya, pada Gambar 2 adalah pertanyaan tentang bagaimana pendapat guru dampak dari program gerakan literasi yang dilakukan pemerintah Kota Balikpapan dalam upaya meningkatkan gerakan membaca siswa belajar siswa di sekolah. Hasilnya, sebanyak 41,67 persen guru menjawab ada dampaknya dan sebanyak 41,67 persen guru menilai tidak ada dampaknya, dan 16,67 persen tidak menjawab. Ketika ditanyakan hal demikian, salah satu program pemerintah Kota Balikpapan, yaitu mematikan televisi setelah maghrib hingga jam 11 malam merupakan program lama pemerintah Kota Balikpapan, yang perlahan dinilai mulai kurang diminati siswa dan sudah jarang diterapkan di masyarakat.

Menurut guru mapel Biologi SMAN 1 Balikpapan, pesatnya arus informasi dan tontotan televisi, serta kurangnya arahan dari pihak keluarga salah satu penyebab program tersebut tidak berjalan maksimal dan perlahan luntur. Seyogyanya, menyoroti peran orang tua sebagai salah satu unsur warga sekolah dalam mengembangkan budaya literasi, karena keluarga merupakan unit terkecil dalam masyarakat. Dalam konteks pendidikan, keluarga merupakan sekolah pertama bagi seorang anak. 


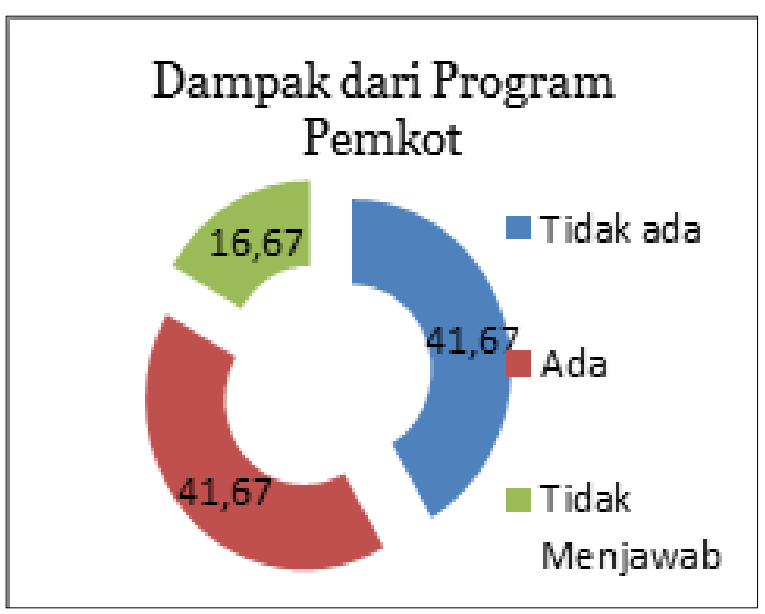

Gambar 2. Dampak dari Program pemerintah kota Balikpapan

Faktor eksternal merupakan faktor yang mempengaruhi prestasi belajar siswa yang bersumber dari luar diri seseorang. Menurut Gunarsa (2004), ada beberapa hal yang mempengaruhi kualitas prestasi belajar siswa. Kondisi lingkungan sekolah yang dapat mempengaruhi kondisi belajar antara lain: adanya guru yang cukup memadai, peralatan belajar yang cukup lengkap serta gedung yang cukup memenuhi syarat untuk belajar. Faktor lingkungan sekolah mempunyai pengaruh yang sangat besar pula, karena hampir sepertiga dari kehidupan anak seharihari berada di sekolah. Faktor lingkungan sekolah yang dapat menunjang keberhasilan belajar anak, di samping gedung, guru dan anak, juga semua faktor lain yang ada di sekolah, seperti: cara penyampaian pelajaran, antara guru dan siswa, asal sekolah, kondisi gedung, serta kelas harus memenuhi syarat belajar dan kedisiplinan yang diterapkan oleh sekolah yang bersangkutan. Lingkungan sekolah turut mendorong minat baca karena seorang anak melakukan kegiatan sesuai yang dilakukan orang-orang di sekelilingnya.

Dari wawancara dengan para guru di tiga sekolah ketika ditanyakan upaya sekolah dalam menumbuhkan gerakan minat baca, seluruh guru pada 3 SMA telah mengetahui upaya masing-masing sekolah dan sangat mendukung dalam menumbuhkan gerakan minat baca siswa. Sebanyak 100 persen atau semua guru menilai bahwa dampak kebijakan sekolah seperti membaca kitab suci di awal pelajaran adalah anak menjadi rajin membaca buku keagamaan karena dibiasakan. Jika hal ini dibiasakan tentu akan memperolah hal positif bagi siswa, sekolah, keluarga dan masyarakat terutama dalam pembentukan dan pendidikan pengembangan karakter. Hal ini seperti diungkap oleh Musliyani (guru Matematika, SMAN 2 kota Balikpapan), diharapkan siswa terinspirasi dan akan lebih santun, lebih hormat pada guru, serta bertambah wawasan.

Pendidikan karakter tidak hanya berlaku demi pendidikan itu sendiri, melainkan juga untuk mempersiapkan individu dapat menjadi warga negara yang bertanggung jawab terhadap keberlangsungan kehidupan dirinya dan keberlangsungan bangsanya (Indriyanto, 2014).

Pada Tabel 3 disajikan berbagai upaya sekolah mendukung gerakan literasi. 


\begin{tabular}{|l|l|l|}
\hline No & Sekolah & $\begin{array}{l}\text { Kebijakan Sekolah dlm upaya } \\
\text { menumbuhkan minat baca }\end{array}$ \\
\hline 1 & SMAN 1 & $\begin{array}{l}\text { Membuat informasi/leaflet di } \\
\text { sekolah untuk mengingatkan } \\
\text { siswa pentingnya membaca; } \\
\text { Program membaca kitab suci } \\
\text { selama 15 menit setiap hari di } \\
\text { awal belajar ; Membuat pojok } \\
\text { lingkungan referensi karya- } \\
\text { karya anak tentang lingkungan, } \\
\text { siswa yang mempunyai rasa } \\
\text { peduli lingkungan diminta } \\
\text { menyumbang buku. }\end{array}$ \\
\hline 2 & $\begin{array}{l}\text { Siswa diwajibkan membaca } \\
\text { Al-Qur'an selama 15 menit } \\
\text { Balikpapan } \\
\text { Mebelum jam belajar dimulai; } \\
\text { untuk lingkungan sekolah akan } \\
\text { mewakili sekolah di lomba } \\
\text { tingkat kota. }\end{array}$ \\
\hline 3 & $\begin{array}{l}\text { Membaca buku selama 10 } \\
\text { menit setiap hari; jika ada } \\
\text { jam kosong, siswa diarahkan } \\
\text { ke perpustakaan. Pada jumat } \\
\text { pulang sekolah setelah } \\
\text { pelajaran siswa diminta ke } \\
\text { mesjid pembelajaran agama. } \\
\text { Siswa yang nonmuslim } \\
\text { dibawa ke aula belajar ibadah } \\
\text { pendalaman iman oleh guru } \\
\text { agama dibantu guru nasrani; } \\
\text { sekolah memberikan layanan } \\
\text { optimal dan penyedia buku- } \\
\text { buku perpustakaan. }\end{array}$ \\
\hline
\end{tabular}

Tabel 3. Kebijakan sekolah dalam Menumbuhkan Minat Baca

Kebijakan sekolah memperlihatkan bahwa ketiga sekolah telah menerapkan program pemerintah kota, yaitu kebiasaan membaca di awal sebelum pelajaran pertama dimulai. Ada hal menarik pada siswa di SMAN 1 Balikpapan sangat diarahkan oleh sekolah dalam gerakan gemar membaca, yaitu dengan membuat pojok lingkungan berupa wadah menampung bagi siswa yang peduli lingkungan dengan menyumbang bukubuku/majalah yang ditaruh di pojok depan kelas namun bukan perpustakaan sekolah, melainkan seperti perpustakaan kelas. Petugas pojok lingkungan ini diatur sedemikian rupa oleh siswa kelas bersangkutan secara bergiliran.

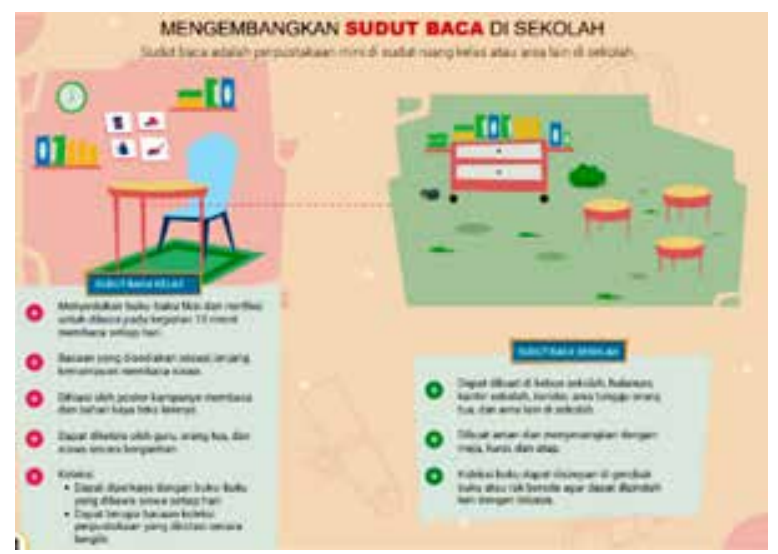

Gambar 3. Pengembangan Sudut Baca di Sekolah. SMAN 1 dan SMAN kota Balikpapan telah mengembangkan sudut baca di sekolah bahkan diantaranya sudut baca di kelas. (Infografis: Panduan praktis GLS)

Pustakawan merupakan tenaga profesional yang mengelola perpustakaan. Dia bertanggung jawab terhadap pengelolaan perpustakaan dan pelayanan perpustakaan. Selain itu dia juga memiliki kewajiban untuk merencanakan program kerja perpustakaan. Apabila sebuah sekolah tidak memiliki tenaga pustakawan, Gerakan Literasi Informasi bisa gagal.

Salah satu tantangan guru dalam meningkatkan prestasi belajar siswa adalah membangkitkan minat siswa untuk gemar membaca. Para guru mengharapkan seharusnya siswa tidak semata bergantung pada guru dalam meningkatkan kualitas pendidikan, karena umumnya cara mengajar di Indonesia cenderung hanya bertumpu pada keahlian guru dalam ceramah. Selain guru bertugas memberi motivasi kepada siswa, siswa juga harus kreatif mencari literasi atau bahan bacaan baik dari media ataupun dari perpustakaan. Mereka menilai bahwa ruang 
perpustakaan, koleksi buku, meja, kursi dan perangkat komputer merupakan sarana dan prasarana yang harus dipersiapkan dengan baik agar GLS dapat berlangsung. Pada kenyataannya sampai sekarang masih banyak mulai sekolah dasar bahkan di sekolah menangah yang sarana dan prasarananya kurang lengkap dan kurang representatif.
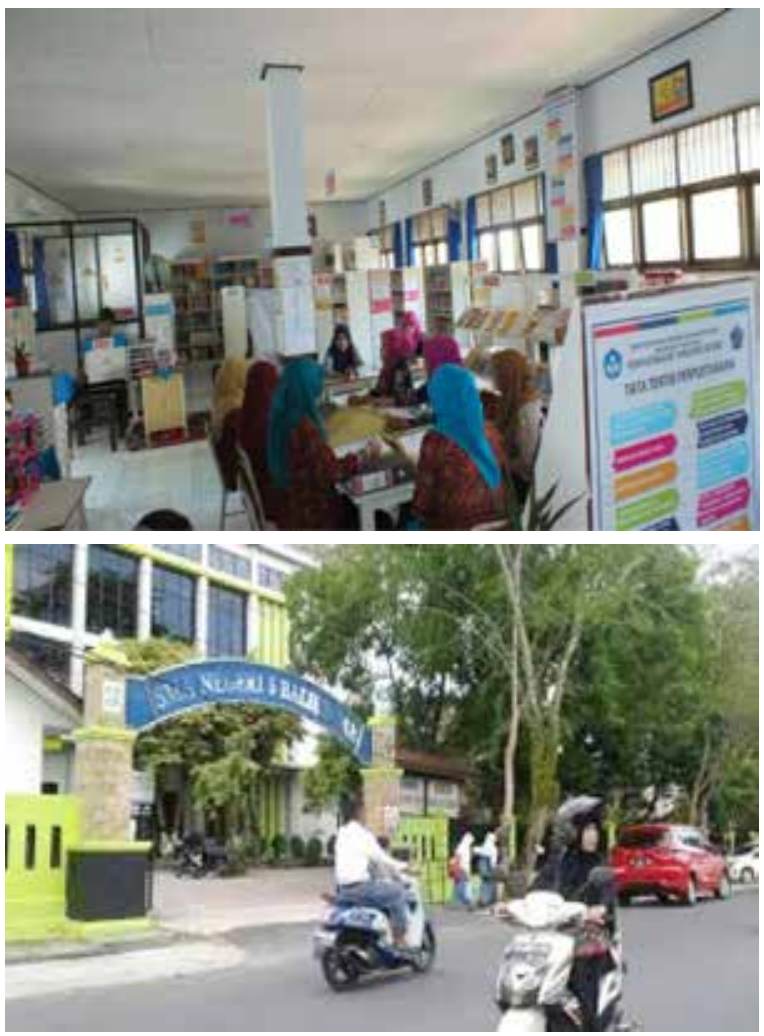

Perpustakaan SMAN 5 Kota Balikpapan ketika mengikuti lomba Perpustakaan tingkat provinsi Kalimantan Timur (Foto: Bsj \& dok.SMAN 5 Balikpapan)

Guru memiliki peran dalam meningkatkan minat baca di kalangan siswa. Peran guru dalam meningkatkan minat baca siswa adalah sebagai kreator, motivator, dinamisator, supervisor, counselor, dan evaluator. Pertama, peran guru sebagai kreator adalah harus lebih kreatif untuk merangsang minat baca para siswanya. Kreativitas dalam diri seorang guru terbentang dari kreativitasnya dalam proses pembelajaran. Guru yang kreatif terkadang malah tidak merasa dirinya "kreatif" karena yang ada dalam keseharian selalu merasa "haus" untuk memberikan strategi mengajar yang terbaik. Cara terbaik merasakan diri kreativitas dalam diri seorang guru adalah jika siswa senang dan fokus saat seorang guru sedang mengajar. Ciri lainnya siswa mengatakan "yaaaa..." saat guru mengakhiripembelajaran. Halinimenandakan bahwa mereka masih menikmati belajar. Kreatif membutuhkan antusiasme dan guru menempatkan diri dalam diri siswa. Kedua, peran guru sebagai motivator adalah harus menjadi seseorang yang selalu mendorong dan memotivasi anak untuk mewujudkan minat baca yang tinggi. Ketiga, peran guru sebagai dinamisator adalah mengatur dan mengelola semua kegiatan membaca anak dengan mendinamiskan seluruh bacaan yang ada. Keempat, peran guru sebagai supervisor adalah mengawasi proses membaca anak, baik dalam jarak dekat maupun jarak jauh agar anak selalu merasa ada yang mengawasinya. Kelima, peran guru sebagai counselor adalah memberikan petunjuk-petunjuk untuk menciptakan suasana psikologis yang kondusif demi terwujudnya jiwa, semangat dan motivasi dalam membaca yang optimal, serta peran guru sebagai evaluator adalah memberikan respon terhadap seluruh kegiatan membaca anak dan menilai hasil bacaan anak dengan memberikan kesempatan untuk menyampaikan hasil pemahaman terhadap yang dibacanya.

Pada Tabel 4 menggambarkan upaya guru SMA di Balikpapan dalam menumbuhkan minat baca, yaitu sebagian besar guru masih menyuruh siswa untuk membaca kemudian menceritakan materi yang dibaca, serta memberi tugas latihan soal-soal. Hal ini diharapkan agar siswa mau tidak mau 
membuka dan membaca buku. Seperti yang disampaikan, Syahrulyani (guru mapel bahasa Inggris) dan Santoso Adi (guru mapel Matematika) di SMAN 1 Balikpapan menyebutkan dampak dari upaya ini adalah siswa mau tidak mau membuka buku dan mengurangi pengaruh teknologi seperti game online. Dengan sendirinya perlahan akan tumbuh minat baca. Pola seperti ini menunjukkan bahwa kebiasaan membaca siswa masih sebatas karena ada tugas, belum kepada kesadaran dari siswa bersangkutan. Bagaimana caranya guru menjadikan siswa senang dan fokus saat seorang guru sedang mengajar.

Upaya lain adalah guru memancing kreativitas siswa, seperti yang dilakukan oleh guru mapel Biologi di SMAN 1 Balikpapan, yaitu guru memberi teks, siswa membahas dalam resume tiap kelompok dilakukan presentasi. Guru tidak menyuruh namun melepas satu pokok bahasan dengan membagi tugas siswa diminta mencari referensi. Siswa menjadi kreatif dengan memanfaatkan jaringan multimedia dan menggunakan IT sebagai panduan melakukan presentasi di kelas. Tidak heran, menurut Tutut Supriyati, banyak bermunculan moderator-moderator terbaik dari hasil presentasi. Yang menarik, sebagai upaya daya tarik siswa dalam menumbuhkan minat baca, terdapat guru mapel Matematika di SMAN 2 Balikpapan, justru sebelum mengajar melakukan pola pembelajaran dengan selingan menceritakan tokoh yang berhasil agar diharapkan akan menjadi insprirasi siswa. Selain itu, siswa disarankan membaca agar termotivasi. Guru juga melakukan sosialisasi terbitan bukubuku perpustakaan agar mereka mau datang ke perpustakaan. Guru tersebut juga senang sekali ke perpustakaan umum (Perpustakaan kota Balikpapan) yang sudah ada jaringan internet. Terdapat juga guru yang menanyakan berapa buku yang telah dibaca, seperti yang dilakukan oleh guru mapel bahasa Indonesia di SMAN 5 Balikpapan. Dalam hal ini guru tidak membatasi bahan bacaan selama tidak mengandung suku, agama, ras, dan antargolongan (SARA). Lalu, siswa diminta menceritakan apa yang pernah dibaca.

Tabel 4. Upaya Guru dalam Menumbuhkan Minat Baca SMA di Balikpapan

\begin{tabular}{|llll|}
\hline No. & Sekolah & $\begin{array}{c}\text { Guru } \\
\text { Mapel }\end{array}$ & Kebijakan Guru Dalam Menumbuhkan Minat Baca \\
Siswa
\end{tabular}




\begin{tabular}{|llll|}
\hline No. & Sekolah & \multicolumn{1}{c|}{$\begin{array}{c}\text { Guru } \\
\text { Mapel }\end{array}$} & Kebijakan Guru Dalam Menumbuhkan Minat Baca \\
Siswa
\end{tabular}

\section{SIMPULAN}

Dampak kebijakan gerakan yang dicanangkan pemkot Balikpapan bagi guru belum seutuhnya menyentuh semua guru, gerakan minat baca masih identik dengan guru pada mapel terkait seperti guru Bahasa Indonesia. Adapun program pemkot yang pernah ada seperti mematikan televisi selepas maghrib pukul 18.00 hingga pukul 23.00 malam, dinilai oleh para guru sudah mulai luntur diterapkan oleh para siswa.

Sekolah mempunyai peranan sangat penting untuk membudayakan minat baca siswa, tidak hanya ketersediaan sarana perpustakaan melainkan pula ketersediaan fasilitas dan bahan bacaan yang menarik, terbitan daftar buku, mengadakan lomba minat baca, memilih siswa teladan membaca buku terbanyak, menjalin kerja sama antar perpustakaan sekolah dalam promosi membaca. Meski kenyataannya masih banyak sekolah masih sulit menyediakan sudut baca di ruang kelas.

Belum semua guru berupaya menciptakan lingkungan yang kondusif bagi tumbuhnya minat baca siswa. Di sekolah, guru hanya sebatas memberikan tugas kepada siswa dan mengarahkan untuk rajin membaca buku dengan memanfaatkan literatur yang ada di perpustakaan atau sumber belajar lainnya.

Belum semua guru memiliki kesadaran mengembangkan budaya literasi, guru lebih 
fokus kepada materi pelajaran, padahal guru dapat memberi tugas membaca setiap minggu pada siswa dan melaporkan hasil bacaan, selain itu menciptakan permainan-permainan yang mempromosikan minat baca. Bisa juga, menceritakan orang-orang sukses sebagai hasil bacaan, menugaskan siswa untuk menyusun abstrak atau sinopsis dari bukubuku yang dibaca, menerbitkan majalah dinding, menyelengarakan jam cerita (story telling) kepada para siswa secara periodik, memberikan hadiah buku untuk hari ulang tahun siswa dan untuk yang berprestasi tinggi, mengajak siswa ke tempat-tempat penerbitan suarat kabar.

\section{REKOMENDASI}

\section{Pemerintah daerah}

Pemerintah Kota (Pemkot) Balikpapan sebaiknya melakukan reviu ulang program penumbuhan minat baca di daerah tidak hanya untuk siswa namun program literasi untuk siswa, sekolah dan masyarakat yang sesuai dengan perkembangan zaman. Pemkot harus berperan dalam menyediakan bahan bacaan yang murah bagi sekolah-sekolah atau menyediakan bahan bacaan di tempat-tempat publik seperti di kantor desa, kecamatan, sampai kepada kantor-kantor pemerintah maupun swasta, sehingga pada waktu senggang anak-anak atau orang-orang yang sedang menunggu pelayanan pemerintah bisa menggunakan waktu untuk membaca. Pemkot harus menyiapkan tenaga pustakawan khusus di sekolah dengan memberi pelatihan kepustakawan.

Jika pemkot ingin lebih serius meningkatkan literasi di masyarakatnya, sebaiknya pemkot Balikpapan belajar dari apa yang dilakukan oleh pemkot Surabaya. Banyak program yang dicanangkan pemkot setempat dalam usaha meningkatkan minat baca, kota Surabaya dikenal sebagai salah satu kota literasi yang memiliki ribuan taman bacaan masyarakat (TBM) yang tersebar di kampung-kampung, sekolah-sekolah, taman kota, dan pondok pesantren.

\section{Sekolah}

Sekolah perlu memberikan ruang yang luas bagi pelaksanaan GLS, tidak sekedar penyediaan sarana baca akan namun juga pengelolaan literasi yang sederhana dengan menyesuaikan situasi dan kondisi lingkungan sekolah. Sekolah harus memberikan penghargaan seperti Reading Award, merupakan kegiatan yang dirancang untuk memberikan penghargaan membaca bagi siswa terbanyak membaca buku baik berskala tingkat masing-masing sekolah, kabupaten/ kota maupun tingkat provinsi, hal ini bertujuan agar merangsang siswa agar terus membaca.

\section{Guru}

Alangkah baiknya dalam proses pembelajaran di sekolah, selain guru mengarahkan kepada siswa untuk rajin membaca buku dengan memanfaatkan literatur yang ada di perpustakaan atau sumber belajar lainnya, guru dapat memberikan tugas kepada siswa untuk menceriterakan kembali buku yang telah dibaca, mengadakan lomba meresensi buku, bedah buku, pameran buku bekerjasama dengan penerbit dan masyarakat pecinta buku.

Jika guru sebagai designer of instruction atau perancang pengajaran, maka guru harus mampu untuk merencanakan atau merancang kegiatan belajar mengajar secara efektif dan efisien. Memahami tahap perkembangan literasi peserta didik dan menerapkan program literasi secara berimbang, yaitu dengan 
strategi pembiasaan dan pembelajaran literasi yang tepat sesuai kebutuhan perkembangan siswa. Guru dengan fungsi sebagai evaluator of student learning, harus mampu melakukan evaluasi yang bervariasi sehingga siswa tidak merasa bosan dan tertekan.

\section{Orang tua}

Di rumah, orang tua harus dapat menciptakan kondisi lingkungan agar anak gemar membaca. Para orang tua hendaknya menyediakan bacaan di rumah, seperti majalah, koran, kamus, buku ilmu pengetahuan, dan sebagainya.

Selama ini, gaung literasi hanya ramai di sekolah, sementara di lingkungan keluarga hampir tidak terdengar. Sebaiknya literasi merupakan urusan semua elemen yang terkait dengan pendidikan, termasuk orang tua. Intinya, peran orang tua harus dikuatkan dalam menyukseskan gerakan literasi.

\section{DAFTAR PUSTAKA}

Ahmad, Arif. Bangsa Tunas Baca. Kompas, 28 September 2016.

Ahuja, Pramila dan G.C. Ahuja. 2010. Membaca Secara Efektif dan Efisien. Bandung: PT: Kiblat Buku Utama, hal. 7.

Gewati, Mikhael. 2016. Minat baca Indonesia ada di Urutan ke-60 Dunia, Kompas, 29 Agustus 2016.

Ginting, V. 2005. Penguatan Membaca, Fasilitas Lingkungan Sekolah dan Ketrampilan Dasar Membaca Bahasa Indonesi a serta Minat Baca Murid. Jurnal Pendidikan Penabur, No.04/Th. IV/ Juli, h.17-35.

Gunarsa, Singgih D. 2008. Psikologi Anak: Psikologi Perkembangan Anak dan Remaja. Jakarta: PT. BPK Gunung Mulia.

Hindarto, Teguh. 18 Desember 2014. Minat Membaca yang Rendah: Akar Persoalan, Dampak Sosial Kuktural, Jalan Keluar. Koran Kebumen Ekspress hal.2.

Ibrahim A., Gufran. 2017. PISA dan Daya Baca Bangsa. Harian Kompas, 29 April 2017, hal. 7.

Indriyanto, Bambang. 2014. Mengkaji Revolusi Mental Dalam Konteks Pendidikan. Jurnal Pendidikan dan Kebudayaan, vol.20 (4), hal. 565.

Kamsul, Khotijah, 2011. Strategi Pengembangan Minat dan Gemar Membaca, hal. 1.

Kementerian Pendidikan dan Kebudayaan. 2017. Peta Jalan Gerakan Literasi Nasional-

Miller, John W. 2016. World's Most Literate Nations Ranked. The World's Most Literate Nations (WMLN) study. Central Connecticut State University di New Britain, CT.

Pratikno, Gandung. 2016. Wawancara dengan Kabid Kurikulum Dinas Pendidikan Kota Balikpapan (wawancara).

Sarnapi, 2015. Masyarakat Indonesia lebih suka Menonton Televisi. Pikiran Rakyat, 30 Mei 2015.

Setiadi, Hari, 2011. Analisis Hasil Peserta Didik Dalam Literasi Membaca melalui Studi Internasional PIRLS 2011. Pusat Penilaian Pendidikan. Balitbang Kemdikbud. 
Sutrisno, Edy. 2009. Manajemen Sumber Daya Manusia, Jakarta: Kencana,hlm. 2.

Kementerian Pendidikan dan Kebudayaan. 2015. Peraturan Menteri Pendidikan dan Kebudayaan Nomor 23, Tahun 2015 tentang Pendidikan Budi Pekerti.

Kementerian Pendidikan dan Kebudayaan, 2016. Hasil PISA Indonesia Tahun 2015 Mengalami Peningkatan. Jakarta, 6 Desember 2016, Biro Komunikasi dan Layanan Masyarakat.

Kementerian Pendidikan dan Kebudayaan, 2016. Peringkat dan Capaian PISA Indonesia Mengalami Peningkatan 06 Desember 2016, Biro Komunikasi dan Layanan Masyarakat.

Kementerian Pendidikan dan Kebudayaan. 2017. Panduan Praktis Geragan Literasi Sekolah. Ditjen Dikdasmen.

Pusat Data dan Statistik Pendidikan dan Kebudayaan. 2018. Statistik Persekolahan SMA 2017/2018. Jakarta: Kemdikbud.

Republik Indonesia. 2007. Undang-Undang Nomor 43 Tahun 2007 tentang Perpustakaan Bab XIII pasal 48.

-----, Tentang PISA, http://litbang.kemdikbud.go.id/index.php/survei-internasional-pisa/ tentang-pisa. Diakses pada tanggal 20 Mei 2017.

-----, Peringkat PISAIndonesia alami peningkatan, http://www. antaranews.com/berita/600165/ peringkat-pisa-indonesia-alami-peningkatan Diakses pada tanggal 20 Mei 2017.

Pressreader Kompas. 2016. Melek Media di Media Sosial, https://www.pressreader. com/ indonesia/kompas/20161202. Diakses pada tanggal 6 Maret 2017.

-----, Minat Baca di Indonesia Rendah. Koran Jakarta: 8 Desember 2016.

Wordpress.com, 2017. Menengok budaya membaca (buku) di beberapa negara. Desfortinmenulis. Diakses pada tanggal 9 Maret 2017.

Zulfannur, Muhammad Dkk. (2010). Menurunnya Minat Baca Buku Dikalangan Siswa

SMAN 1 Lhokseumawe. Aceh: SMAN 1 Lhokseumawe. 